\title{
Consolidation Behaviour of The Neutralisation Spent Pickle Liquor (NSPL) Sludge from Steel Works
}

\author{
(Kelakuan Mampatan Enapcemar Neutralisation Spent Pickle Liquor (NSPL) dari Kerja-Kerja Keluli) \\ N. N. Nik Daud*, H. R. Thomas \& S. Seetharam
}

\begin{abstract}
The disposal of industrial waste sludge at a landfill has become a global problem especially when dealing with high moisture content material. Neutralisation Spent Pickle Liquor (NSPL) sludge waste generated in steel industry has been categorized as one of the slurry wastes in geotechnical engineering and poses serious handling problem due to its high water content. The NSPL sludge waste is categorized as a high water content material with a low solid concentration.The main objective in this paper is present a study related to compressive behaviour of the NSPL sludge material under external load. A series of consolidation tests of different NSPL initial water content and load pressure using Rowe cell equipment were performed. The consolidation behaviour of the NSPL sludge was shown to be complex, especially during the initial stages of the loading process. For any given load increment, an instantaneous compression was observed but no pore water dissipation were detected. The coefficient of permeability was found to be very high during the first few minutes, i.e. in the range of $10^{-4}-10^{-5} \mathrm{~m} / \mathrm{s}$, and reduces significantly to $10^{-10} \mathrm{~m} / \mathrm{s}$ after the first 17 hours of the test. The compression behaviour of the sludge materials are directly related to their coefficient of permeability.
\end{abstract}

Keywords: Sludge; high water content; consolidation; pore water pressure; coefficient of permeability

ABSTRAK

Pelupusan bahan sisa enapcemar perindustrian di tapak kambusan telah menjadi masalah besar terutama bahan sisa enapcemar yang mengandungi kadar air yang tinggi. Sisa enapcemar hasil daripada industri keluli dikenali sebagai Neutralisation Spent Pickle Liquor (NSPL) telah dikategorikan sebagai salah satu sisa enapcemar atau lumpur cair di dalam kejuruteraan geoteknikal dan mempamerkan masalah besar pengendalian disebabkan kandungan air yang tinggi. Sisa enapcemar NSPL dikategorikan sebagai bahan sisa yang berkelembapan tinggi dengan kepekatan bahan pepejal yang rendah. Objektif utama kertas kerja ini ialah untuk membentangkan satu kajian mengenai kelakuan mampat bahan sisa enapcemar NSPL yang dikenakan beban luar. Satu siri ujian mampatan yang berbeza kandungan air awal NSPL dan tekanan beban menggunakan peralatan sel Rowe telah dijalankan. Kelakuan mampatan sisa enapcemar NSPL amat kompleks, terutama pada tahap awal proses pembebanan. Setiap tokokan beban, mampatan segera berlaku tetapi tiada tekanan air liang dikesan. Pemalar kebolehtelapan amat tinggi pada minit pertama, iaitu dalam julat $10^{-4}-10^{-5} \mathrm{~m} / \mathrm{s}$, dan berkurangan sehingga $10^{-10} \mathrm{~m} / \mathrm{s}$ selepas 17 jam pertama ujian mampatan. Kelakuan mampatan sisa enapcemar adalah berkait terus dengan pemalar kebolehtelapannya.

Kata kunci: Enapcemar; kandungan air tinggi; mampatan; tekanan air liang; pemalar kebolehtelapan

\section{INTRODUCTION}

The disposal of high water content soil-like wastes and reclamation of the disturbed land pose one of the major challenges facing geotechnical engineers. The high water content (often slurried) wastes, produced by a wide variety of mining and beneficiation processes are usually discharged hydraulically into a diked impoundment area or open lagoons. The problems related to the slurry wastes (dredged waste, waste water sludge, paper waste sludge) are high water content, low strength, low hydraulic conductivity and high compressibility (Krizek 2000; Quiroz et al. 2000; Berilgen et al. 2006).

Koenig et al. (1996), Bo et al. (2002a, 2002b \& 2003), Lo et al. (2002) and O'Kelly (2005) explained the consolidation process of high water content materials (i.e. ultra-soft soil, slurry waste materials). They concluded that the high water content materials undergo large strain with little dissipation of pore pressure and with little increase in effective pressure at the initial stage under an external load. However, the phenomenon of large deformation of 
the material and the slow dissipation of excess pore water pressure at the initial stage under constant loading has not yet been studied.

In this paper, an investigation was carried out to study the settlement and pore water dissipation behaviour of the Neutralisation Spent Pickle Liquor (NSPL) sludge material at initial stage of one-dimensional consolidation process. A series of one-step pressure loading tests were carried out using a hydraulic consolidation cell (Rowe cell).

\section{APPARATUS, SAMPLE PREPARATION AND METHODS}

\section{APPARATUS}

Details on Rowe cell can be found in Rowe and Barden (1966) and Head (1986). In this study, the cell used has the inner diameter of $152 \mathrm{~mm}$, and the initial sample thickness is approximately $40 \mathrm{~mm}$. This dimension of cell provides a $\mathrm{D} / \mathrm{H}$ ratio of 3.8 , which satisfies the $\mathrm{D} / \mathrm{H}$ ratio of 3.0 recommended by Mesri et al. (1995) and Yoshikuni et al. (1995). This requirement is needed to avoid testing problems such as ring friction and variation of lateral pressure during consolidation and also to maintain a constant total stress condition for a long period.
A free strain loading was applied in this study with drainage conditions at the top of the sample. Displacements were measured using Linear Strain Conversion Transducer (LSCT) type HS50B, Model No. MPE 2788-50 manufactured from MPE Transducers Ltd. It has maximum travel of $50 \mathrm{~mm}$ and has an accuracy of $0.001 \mathrm{~mm}$. Pore pressures were measured using pore pressure transducers Model No. WF 17060, which have an accuracy of $1 \mathrm{kPa}$. The pore pressure was measured at the center of cell base. The volume change was measured by volume change equipment Model No. WF 17044 with an accuracy of 0.001 $\mathrm{mL}$. Pore pressure transducer and volume change apparatus were manufactured from Wykeham Farrance, UK. All the measured data were logged by an advanced data logger Model CR10X manufactured by Campbell Scientific and transferred to computer nearby that contains data logger support software, PC208W3.3.

Figure 1 show the schematic of the Rowe cell used in this study. From Figure 1, the drainage outlet at D is led into a volume change device which can measure volume of drainage flow. In these tests, the load was maintained constant on the sample after the end of consolidation (pore water pressure completely dissipated) to observe secondary compression. When the pore pressure has fallen to the initial value, the consolidation process is complete.

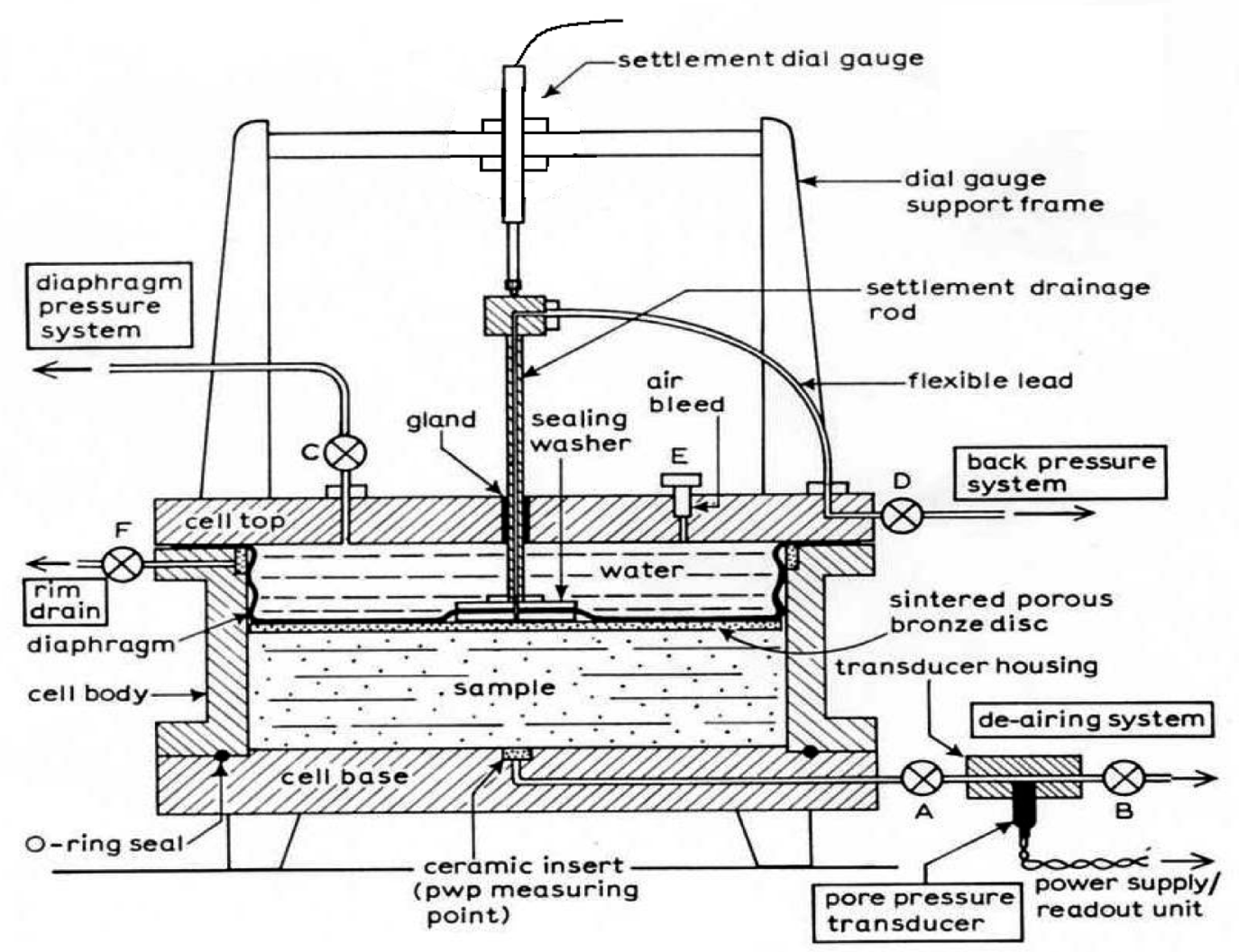

FIGURE 1. Schematic of The Rowe Cell Equipment 


\section{SAMPLE PREPARATION}

The Neutralisation Spent Pickle Liquor (NSPL) sludge waste materials were obtained from a steel works lagoon in Cardiff, United Kingdom, using a grab dredger and stored in plastic containers at room temperature in the laboratory. The NSPL has high moisture content, i.e. $186 \%$, which is greater than its liquid limit and low solid concentration, i.e. $35.5 \%$.

The initial moisture content varied in the range of $100 \%$ to $250 \%$. The required moisture content consistency was changed by wetting the material with slurry fluid. Procedure in sample preparation and applying pressure are described in detail by Head (1986) and in BS 1377:1990 where the apparatus is described as a hydraulic consolidation cell.

\section{METHODS}

To understand the settlement behaviour of the NSPL sludge waste, an experimental program consisted of two approaches with varying initial moisture content of NSPL and applied pressure were carried out. The details of the initial conditions of the tests are presented in Table 1. Four samples were prepared with initial moisture contents of $100 \%, 150 \%, 200 \%$ and $250 \%$. The one-step pressure loading was carried out at four different values $(10 \mathrm{kPa}$, $20 \mathrm{kPa}, 30 \mathrm{kPa}$, and $40 \mathrm{kPa}$ ), hence 16 tests have been carried out in total. This condition is similar to the case of reclamation over a slurry or waste pond in which one-step pressure loading is applied on the soft slurry.

The initial pore water pressure of $10 \mathrm{kPa}$ (at each of the initial stage of process before applied pressure) is due to the pore water pressure generated by the head of water in the supply tank. Theoretically, the supply tank should generate a pressure of $12.5 \mathrm{kPa}$; i.e. the header tank is $1.25 \mathrm{~m}$ above the pore water pressure transducer. At the final stage of equalization, each of the samples will have a $10 \mathrm{kPa}$ effective pressure due to the net pressures.

\section{RESULTS AND DISCUSSIONS}

The results from the consolidation tests are presented in this section. The behaviour of settlement-pore water pressure dissipation will be discussed in terms of settlement and void ratio, dissipation of pore water pressure and permeability.

Table 1 show details of the tests in terms of initial and final parameters of each test, i.e. thickness of sample, initial moisture content, initial void ratio, $e_{0}$, and final void ratio, $e_{f}$, and final strain, $\varepsilon$ and total settlement measured from volume change device and displacement transducer. Thickness of each sample, initial moisture content and initial void ratio was measured and calculated after the equalization stage was completed. From the table, it can be seen that the final strain, $\varepsilon$, of the sludge material increases with increase in initial moisture content and applied pressure. It also has been observed that the total settlement measured from volume change and dial gauge agree with each other which indicated that consolidation settlement takes place in the sample upon the applied pressure.

TABLE 1. Initial and Final Conditions of Samples

\begin{tabular}{|c|c|c|c|c|c|c|c|}
\hline \multirow{2}{*}{$\begin{array}{l}\text { Tests } \\
\text { Code } \\
\sigma / w \\
(\mathrm{kPa} / \%)\end{array}$} & \multirow{2}{*}{$\begin{array}{c}\text { Thickness } \\
\text { of Sample } \\
(\mathrm{mm})\end{array}$} & \multirow{2}{*}{$\begin{array}{c}\text { Initial } \\
\text { Moisture } \\
\text { Content } \\
(\%)\end{array}$} & \multirow{2}{*}{$\begin{array}{l}\text { Initial Void } \\
\text { Ratio } e_{0}\end{array}$} & \multirow{2}{*}{$\begin{array}{l}\text { Final Void } \\
\text { Ratio } e_{f}\end{array}$} & \multirow{2}{*}{$\begin{array}{c}\text { Final } \\
\text { Strain, } \varepsilon \\
(\%)\end{array}$} & \multicolumn{2}{|c|}{ Total Settlement } \\
\hline & & & & & & $\begin{array}{c}\text { From } \\
\text { Volume } \\
\text { Change } \\
(\mathrm{mm})\end{array}$ & $\begin{array}{c}\text { From Dial } \\
\text { Gauge } \\
(\mathrm{mm})\end{array}$ \\
\hline $30 / 100$ & 43.7 & 103 & 2.862 & 2.408 & 11.80 & 3.54 & 5.14 \\
\hline $40 / 100$ & 42.6 & 96 & 2.648 & 2.194 & 14.80 & 6.19 & 6.31 \\
\hline $50 / 100$ & 40.1 & 92 & 2.558 & 1.974 & 16.40 & 6.35 & 6.59 \\
\hline $60 / 100$ & 39.8 & 91 & 2.531 & 1.688 & 23.90 & 8.29 & 9.51 \\
\hline $30 / 150$ & 43.6 & 151 & 4.177 & 2.619 & 13.02 & 5.35 & 5.66 \\
\hline $40 / 150$ & 32.0 & 117 & 3.238 & 2.149 & 25.00 & 8.70 & 8.22 \\
\hline $50 / 150$ & 34.6 & 126 & 3.485 & 2.162 & 27.11 & 9.78 & 9.61 \\
\hline $60 / 150$ & 42.8 & 129 & 3.580 & 2.232 & 29.42 & 11.00 & 12.59 \\
\hline $30 / 200$ & 33.1 & 189 & 5.244 & 4.039 & 19.62 & 7.11 & 6.49 \\
\hline $40 / 200$ & 43.8 & 177 & 4.904 & 3.288 & 27.34 & 9.78 & 11.97 \\
\hline $50 / 200$ & 43.4 & 196 & 5.429 & 2.440 & 46.50 & 16.34 & 20.18 \\
\hline $60 / 200$ & 43.5 & 167 & 4.625 & 1.682 & 52.36 & 17.51 & 22.78 \\
\hline $30 / 250$ & 38.6 & 232 & 6.421 & 4.989 & 22.92 & 7.73 & 7.44 \\
\hline $40 / 250$ & 42.3 & 233 & 6.445 & 2.424 & 55.08 & 18.82 & 22.82 \\
\hline $50 / 250$ & 42.5 & 202 & 5.593 & 1.946 & 58.63 & 20.22 & 23.51 \\
\hline $60 / 250$ & 48.7 & 188 & 5.196 & 1.782 & 60.97 & 25.40 & 26.84 \\
\hline
\end{tabular}


Figure 2 represents settlement-pore water pressure dissipation behaviour of the NSPL waste material $(60 \mathrm{kPa}-$ $150 \%$ and $250 \%$ ). As seen from these curves the behaviour of the material can be split into two phases. In the first phase, large displacements occurred for all samples within 1 minute after the test commenced with little or no pore water pressure dissipation. Subsequently, a slow rate of settlement continued to take place, however with very little or no pore water pressure dissipation until the first few hundred minutes after the application of pressure. The second phase was characterized by a steady rate of settlement accompanied by pore water pressure dissipation.

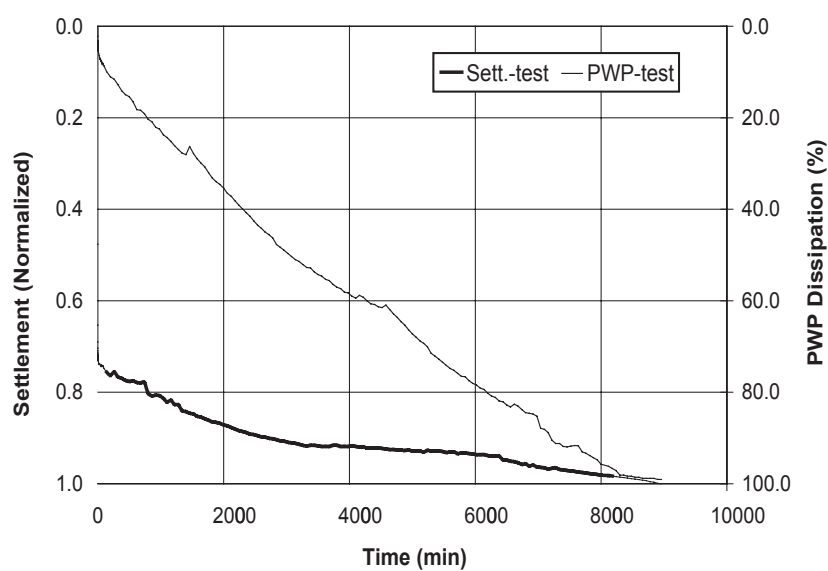

(a)

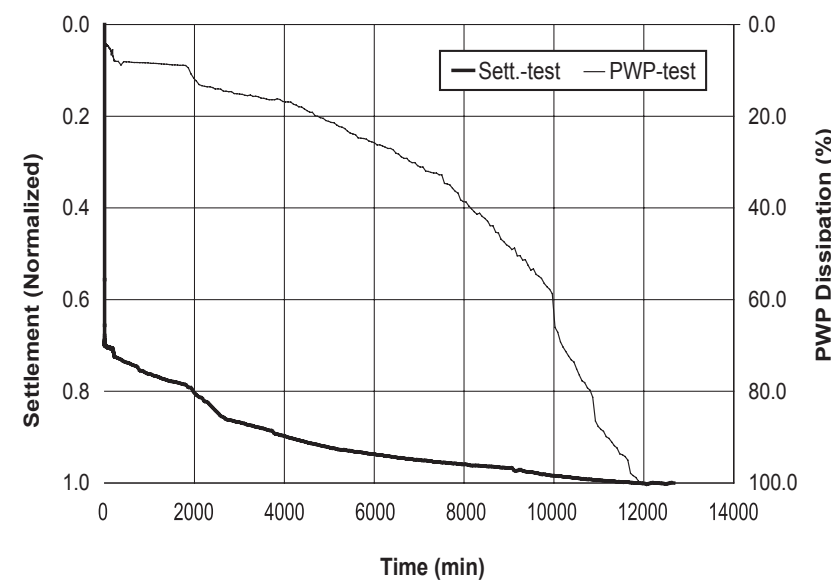

(b)

FIGURE 2. Settlement and Pore Water Pressure Dissipation Versus Time of

(a) $150 \%$

(b) $250 \%$ Initial Moisture Content (Applied Pressure $=60 \mathrm{kPa})$

\section{SETTLEMENT BEHAVIOUR}

As stated above in the first phase, although there was little or no pore water pressure dissipation in the early stages of consolidation process, it has been observed that the
NSPL sludge material exhibits a large deformation for all one-step pressure loading tests. The reason for this can be attributed to the structure of the material. From the physical characteristics investigation carried out on the NSPL sludge, it was concluded that the NSPL sludge possess a flocculatedaggregated structure. This would have been formed under the in-situ condition after the sedimentation stage. This structure means that the bulk material has a large number of flocculated clusters. These clusters along with the pore water (with its chemical concentration) develop an interparticle bond that allows the overall structure to exist under higher void ratios. When the bond is broken i.e. by mechanical means (Rowe cell), this structure is destroyed and display high compressibility.

From Figure 2, it is also evident that the magnitude of settlement at the first phase is dependent on the initial moisture content and applied pressure. For instance, as seen in Table 2, for $100 \%, 60 \mathrm{kPa}$ test, the settlement was found to be $5.89 \mathrm{~mm}$. Whereas for $250 \%, 60 \mathrm{kPa}$ test the magnitude of settlement was found to be $21.86 \mathrm{~mm}$. This is expected since higher initial moisture content material has higher free water content that can be removed by external load. Similarly, the total consolidation settlement also depends on the initial moisture content and applied pressure.

Table 2 presents the compressibility parameters for the NSPL sludge. The compressibility parameters during the large deformation of the sample which is at first phase of consolidation process where the material is in a slurry condition is presented in terms of compression index, $C_{c}$, settlement and strain, $\varepsilon$. These compressibility coefficients are an expression of change in void ratio and ratio of effective pressure.

It has been observed that compressibility increase as the initial moisture content and applied pressure increase. It can be concluded that at the first phase, the compressibility of the sample is high. It is believed that at first stage, the compressibility of high moisture content material is high because the volume change is due solely to reduction of water. This behaviour is similar to ultra-soft soil investigated by Bo et al. (1999) having an initial moisture content of $130-190 \%$.

Whilst, the above discussion focused on the unusual behaviour of settlement during the first phase, including the effect of initial moisture content and applied pressure, attention is now drawn to physico-chemical aspects of the material. Figure 3 presents the behaviour of void ratio versus time for the 30 and $40 \mathrm{kPa}$ test varied by initial moisture content $(100 \%, 150 \%, 200 \%$ and $250 \%)$ which is also equivalent to the void ratio versus effective pressure during the test. If there were no chemical forces operating, then irrespective of the initial moisture contents, the final void ratio for the same pressure will be similar. However, from Figure $3 b$, it is evident that the final void ratios are different depending on the initial moisture contents. This suggests that in addition to physical interaction (due to applied pressure), chemical interaction are also operating. 
TABLE 2. Comparisons of Compressibility Parameters of Samples

\begin{tabular}{|c|c|c|c|c|c|c|c|}
\hline $\begin{array}{l}\text { Tests } \\
\text { Code } \\
\sigma / w \\
(\mathrm{kPa} / \%)\end{array}$ & $\begin{array}{l}\text { Coefficient } \\
\text { of } \\
\text { consolidation } \\
c_{v}\left(\mathrm{~m}^{2} / \mathrm{yr}\right)\end{array}$ & $\begin{array}{l}\text { Coefficient } \\
\text { of volume } \\
\text { compressibility } \\
m_{v}\left(\mathrm{~m}^{2} / \mathrm{MN}\right)\end{array}$ & $\begin{array}{l}\text { Coefficient } \\
\text { of } \\
\text { permeability } \\
k(\mathrm{~m} / \mathrm{s})\end{array}$ & $\begin{array}{l}\text { Secondary } \\
\text { compression } \\
C_{\alpha}\end{array}$ & $\begin{array}{l}\text { During } \\
{ }^{*} C_{c}\end{array}$ & $\begin{array}{l}\text { Initial } \\
* \Delta H \\
(\mathrm{~mm})\end{array}$ & $\begin{array}{l}\text { phase } \\
*_{\varepsilon} \\
(\%)\end{array}$ \\
\hline $30 / 100$ & 0.15 & 11.80 & $5.54 \mathrm{E}-10$ & 0.002 & 0.55 & 1.89 & 4.30 \\
\hline $40 / 100$ & 0.14 & 6.22 & $2.79 \mathrm{E}-10$ & 0.006 & 0.50 & 2.77 & 6.50 \\
\hline $50 / 100$ & 0.13 & 5.47 & $2.17 \mathrm{E}-10$ & 0.007 & 0.62 & 4.18 & 10.40 \\
\hline $60 / 100$ & 0.09 & 5.97 & $1.69 \mathrm{E}-10$ & 0.001 & 0.75 & 5.89 & 14.80 \\
\hline $30 / 150$ & 0.17 & 13.0 & $6.98 \mathrm{E}-10$ & 0.035 & 0.69 & 1.96 & 4.50 \\
\hline $40 / 150$ & 0.11 & 12.8 & $4.30 \mathrm{E}-10$ & 0.030 & 1.05 & 3.78 & 11.80 \\
\hline $50 / 150$ & 0.11 & 9.83 & $3.33 \mathrm{E}-10$ & 0.020 & 1.40 & 6.50 & 18.79 \\
\hline $60 / 150$ & 0.11 & 7.36 & $2.58 \mathrm{E}-10$ & 0.019 & 1.48 & 9.65 & 22.54 \\
\hline $30 / 200$ & 0.16 & 18.00 & $9.01 \mathrm{E}-10$ & 0.044 & 1.34 & 2.14 & 6.47 \\
\hline $40 / 200$ & 0.15 & 13.70 & $6.47 \mathrm{E}-10$ & 0.039 & 1.76 & 6.23 & 14.21 \\
\hline $50 / 200$ & 0.09 & 15.50 & $4.57 \mathrm{E}-10$ & 0.022 & 2.81 & 11.43 & 26.34 \\
\hline $60 / 200$ & 0.08 & 13.10 & $3.44 \mathrm{E}-10$ & 0.020 & 2.73 & 14.75 & 33.90 \\
\hline $30 / 250$ & 0.22 & 21.90 & $1.49 \mathrm{E}-09$ & 0.057 & 2.03 & 3.17 & 8.21 \\
\hline $40 / 250$ & 0.09 & 27.00 & $7.75 \mathrm{E}-10$ & 0.049 & 3.11 & 8.42 & 19.91 \\
\hline $50 / 250$ & 0.09 & 18.40 & $5.23 \mathrm{E}-10$ & 0.025 & 3.77 & 14.64 & 34.44 \\
\hline $60 / 250$ & 0.07 & 13.80 & $2.90 \mathrm{E}-10$ & 0.023 & 3.98 & 21.86 & 44.89 \\
\hline
\end{tabular}

* Compression index $-C_{c}$; settlement $-\Delta H$; strain $-\varepsilon$

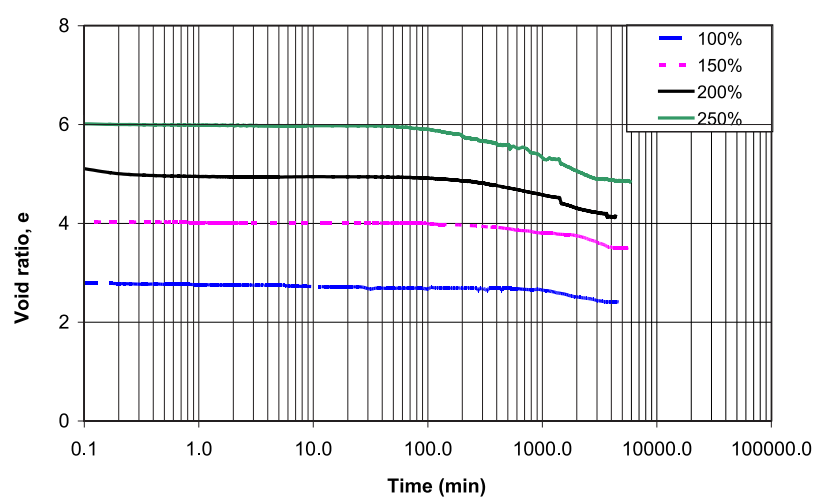

(a)

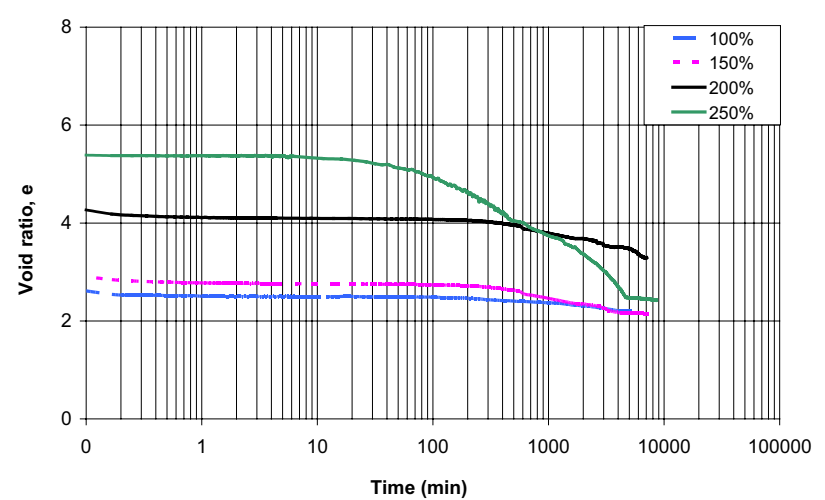

(b)

FIGURE 3. Void Ratio Versus Time of

(a) $30 \mathrm{kPa}$

(b) $40 \mathrm{kPa}$ Applied Pressure (One Step Pressure Loading Tests)

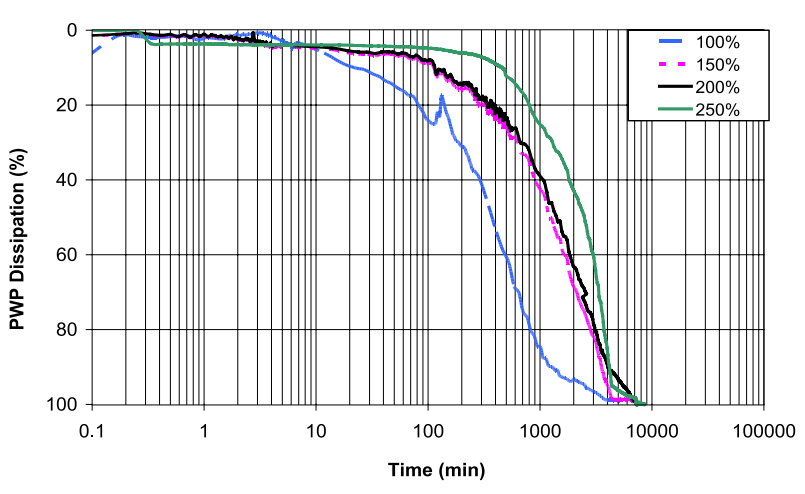

(a)

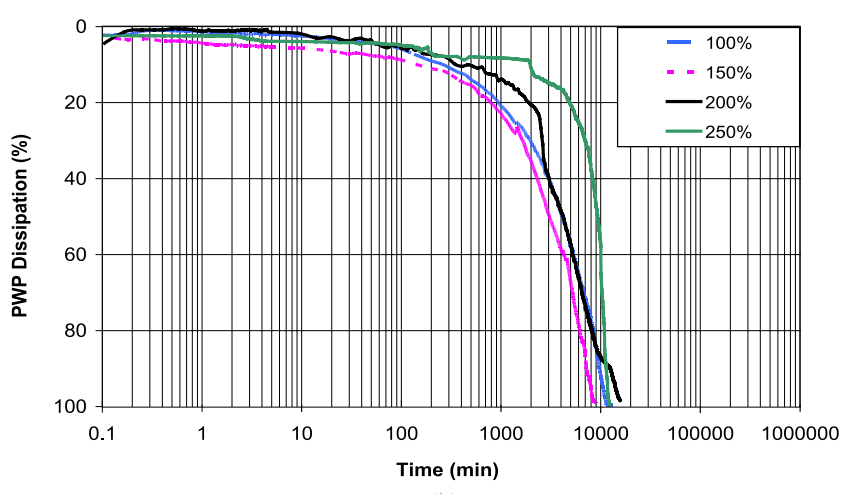

(b)

FIGURE 4. Pore Water Pressure Dissipation Versus Time of

(a) $40 \mathrm{kPa}$

(b) $60 \mathrm{kPa}$ Applied Pressure (One-Step Pressure Loading Tests) 


\section{PORE WATER PRESSURE MEASUREMENTS}

The pore water pressures are measured at the base of the cell using the pore water pressure transducer. From pore water pressure dissipation representative curves (Figure 4), it is indicated that the period of pore water pressure delay for each test varies slightly. The commencement of pore water pressure dissipation for the 40 and $60 \mathrm{kPa}$ tests at different initial moisture content was found to be around 100 to 300 minutes and 200 to 1000 minutes, respectively. The higher the initial moisture contents, the longer the period of pore water pressure to dissipate.

There is possible hypothesis for this behaviour, i.e. the delay in pore water pressure dissipation during the initial stage of consolidation is due to bound water effect. Klein and Sarsby (2000) attributed this sludge consolidation feature mainly to the microstructure of the sludge particles. They found that during consolidation some pore water which exists as liquid trapped within the floc structure became free water and thus continuously provides a source of additional pore water, which compensated for the dissipated pore water. Similar behaviour also occurred in sewage sludge material (Lo et al. 2002) and ultra-soft soil (Bo et al. 1999). It can be concluded that this regeneration of pore water significantly reduces the rate of primary consolidation of the NSPL sludge.

\section{COEFFICIENT OF PERMEABILITY, $k$}

The settlement behaviour is directly related to the coefficient of permeability of the samples. In the case of high moisture content material, two different approaches for two different stages were used to obtain the coefficient of permeability, $k$.

In the slurry stage (first phase), Equation (1) derived from Darcy's Law was implemented for calculating the coefficient of permeability during the consolidation process especially at the initial stage. Solid velocity, $v_{s}$, is simply the rate of change in height of the sample. The hydraulic gradient, $i$, can be determined from the pore water pressure measurements (Been and Sills 1981).

$$
k=-\left(\frac{v_{s}}{i}\right)
$$

Where

$k=$ coefficient of permeability $(\mathrm{m} / \mathrm{s})$

$v_{s}=$ velocity of the solid $(\mathrm{m} / \mathrm{s})$

$i \quad=$ hydraulic gradient

Figure 5 shows typical results of permeability against time in a logarithmic scale during the consolidation tests for $40 \mathrm{kPa}$ applied pressure at different initial moisture contents. From these tests, it was found that the coefficient of permeability, $k$, of sample at the first phase ranged from $1 \times 10^{-4}$ to $1 \times 10^{-5}$ $\mathrm{m} / \mathrm{s}$. It is suggested that the high permeability at the early stage of consolidation process of high moisture content material occurred because of the availability of larger proportion of free water. Also, the NSPL sludge material has a fragile structure which can easily break down upon a sudden application of load. A similar behaviour has also been encountered by Mesri (1995) for sediment material from physical-chemical point of view. Furthermore, the curves show that the value $k$ decrease with time and the final value of permeability of each test is around $1 \times 10^{-10}$ $\mathrm{m} / \mathrm{s}$. It is suggested that the changes in permeability with time is due to the rearrangement of particles. The closer the particles, the lower the value of permeability of the material.

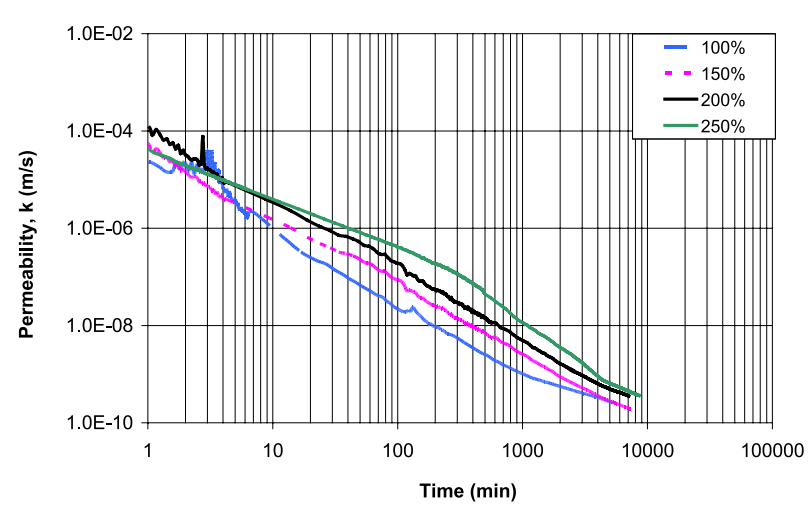

FIGURE 5. Permeability Versus Time of $40 \mathrm{kPa}$ Applied Pressure (One-Step Pressure Loading Tests)

The solid phase refers to the phase where the material is below their liquid limit. For the purpose of computing the equilibrium permeability value, the approach of Casagrande and Taylor's method are adopted for this stage of deformation, i.e. after the initial large deformation stage. This approach of computation of permeability values for high moisture content (waste) material has been adopted by various researchers (Andersland \& Mathew 1973; Colleselli et al. 2000; O'Kelly 2005). The values of the coefficient of permeability, $k$, of the NSPL sludge material in terms of Terzaghi's theory could be calculated directly using Equation (2) with calculated values of coefficient of consolidation, $c_{v}$, (Equation (3)) and coefficient of volume compressibility, $m_{v}$ (Equation (4)). The square-root-of time fitting (Taylor) method was chosen to calculate the coefficient of consolidation, $c_{v}$, because some of the settlement versus logarithm-of-time curves for certain test did not exhibit the typical inverse $S$ shape. The method was adopted for calculation of the needed permeability value, $k$, of the material under each consolidation pressure below the liquid limit stage.

$$
k=c_{v} m_{v} \gamma_{w}
$$

Where

$k=$ coefficient of permeability $(\mathrm{m} / \mathrm{s})$

$c_{v}=$ coefficient of consolidation $\left(\mathrm{m}^{2} / \mathrm{s}\right)$

$m_{v}=$ coefficient of volume compressibility $\left(\mathrm{m}^{2} / \mathrm{kN}\right)$

$\mathrm{g}_{w}=$ unit weight of water $\left(9.8 \mathrm{kN} / \mathrm{m}^{3}\right)$ 
The $\sqrt{ } t$ (Taylor) method is written as

$$
c_{v}=\left(\frac{T_{v} H^{2}}{t_{90}}\right)
$$

Where

$c_{v}=$ Coefficient of consolidation $\left(\mathrm{m}^{2} /\right.$ year $)$

$t_{90}=$ Time at $90 \%$ of consolidation (year)

$H=$ Length of drainage path $(\mathrm{m})$

$T_{v}=0.848$

$$
m_{v}=\frac{1}{1+e_{0}}\left(\frac{e_{0}-e_{1}}{\sigma_{1}{ }^{\prime}-\sigma_{0}{ }^{\prime}}\right)
$$

Where

$m_{v}=$ coefficient of volume compressibility $\left(\mathrm{m}^{2} / \mathrm{MN}\right)$

$e_{0}=$ initial void ratio

$e_{1}=$ void ratio at $\sigma_{1}$

$\sigma_{0}=$ initial effective pressure

$\sigma_{1}=$ effective pressure at $e_{1}$

The results show that the value of permeability, $k$, ranges from $1 \times 10^{-9}$ to $1 \times 10^{-10} \mathrm{~m} / \mathrm{s}$, depending on the initial moisture content and applied pressure; higher initial moisture content will result in higher permeability and the value decreases with increase in the applied pressure. This is because the permeability value is related to the coefficient of volume compressibility, $m_{v}$, and coefficient of consolidation, $c_{v}$ of the sample.

\section{VOID RATIO-EFFECTIVE PRESSURE AND PERMEABILITY-VOID RATIO RELATIONSHIPS}

Figure 6 shows the void ratio versus effective pressure relationship for various initial moisture contents $(100 \%$, $150 \%, 200 \%$ and $250 \%$ ). The slope of $e$-sc, defined as the compression index $\left(C_{c}\right)$, relates directly to the compressibility of the sludge material and is used to estimate the total settlement that will occur in the field. Based on the $e$-s $\phi$ curves obtained from the final value of void ratio, it can be concluded that the slope (coefficient of compressibility, $\left.a_{v}\right)$ or compression index $(C)$ decreases with increasing effective pressure and more importantly is non-linear at initial moisture contents $150 \%, 200 \%$ and $250 \%$. For instance, the values of void ratio, $e$, decreased from 4.989 to 1.782 as the effective pressure increases from $20 \mathrm{kPa}$ to $50 \mathrm{kPa}$ for $250 \%$ initial moisture content sample as shown in Table 2. This is also one of the key observations made by several researchers for high moisture content materials (Aydilek et al. 2000; Bo et al. 2004; O'Kelly 2005), where non-linearity of material parameters have been acknowledged.

The relationship between permeability and void ratio is important in the study of large strain consolidation. The permeability-void ratio $(k-e)$ plot of samples varying with initial moisture content and applied pressure for one-step pressure loading tests is shown in Figure 7. The values of coefficient of permeability, $k$, is obtained from Taylor's method as described in Section 3.3. The $k$ values (solid stage) from Darcy's law show nearly similar value calculated from Taylor's method however in this research study, values calculated from Taylor's method is considered.

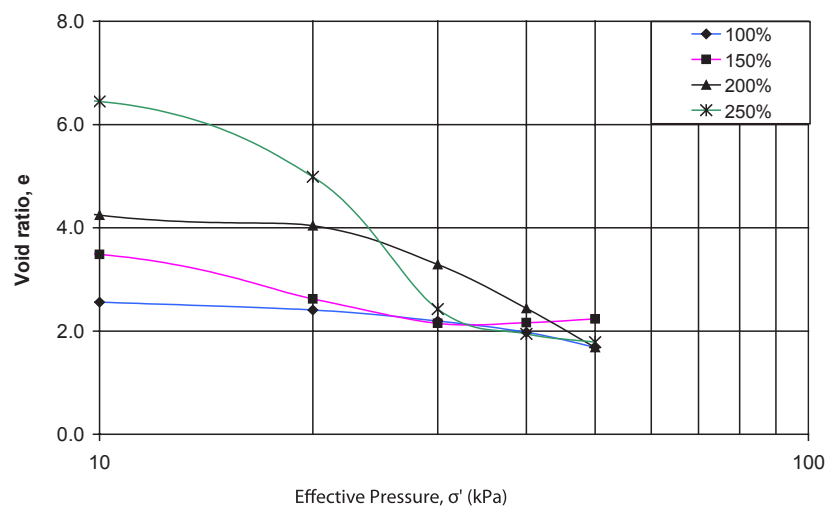

FIGURE 6. Void Ratio Versus Effective Pressure of Different Initial Moisture Content (One-Step Pressure Loading Tests)

It can be seen that the void ratio-permeability is generally non-linear. At higher void ratios, the permeability value is high. This behaviour is due to a higher compressibility at higher void ratio and vice versa. Overall, the $k$ value decreases from $1.4 \times 10^{-9}$ to $1.7 \times 10^{-10}$ $\mathrm{m} / \mathrm{s}$ as the void ratio decreases from 4.989 to 1.682 . This can be attributed to the facts that at lower void ratios, the tortuosity of the porous medium, i.e. the sludge increases.

\section{CONCLUSIONS}

Consolidation tests were carried out on sludge waste with a moisture content varying between $100 \%$ and $250 \%$ under an applied pressure ranging between 30 to $60 \mathrm{kPa}$ for onestep pressure loading tests. A Rowe cell was used to study the settlement and pore pressure behaviour of sludge waste. The following conclusions are drawn from the test results.

The settlement behaviour of the material can be split into two phases. When the sludge waste is subject to an external pressure, the material underwent a large deformation at the first phase. However, during this period (first phase), there is little or no pore pressure dissipation. This behaviour therefore does not follow Terzaghi's consolidation theory. The compression index and settlement in the first phase of consolidation test when there is little or no pore water pressure dissipation is very high and it increases as the initial moisture content increase. The reason for this can be attributed to the open fabric structure of the material.

With regards to the delayed pore water pressure dissipation, the bound water hypothesis suggest that during consolidation some pore water existing as liquid trapped within the floc structure became free water and thus the structure continuously provides a source of additional pore water, which compensated for the dissipated pore 
water. However, at this stage, the proof for the hypothesis is beyond the scope of the current work. This study has hightlight out some unique features of the consolidation behaviour of the NSPL sludge which was classified as a high water content material.

\section{REFERENCES}

Andersland, O. B. and Mathew, P. J. 1973. Consolidation of High Ash Papermill Sludges. ASCE J Soil Mech Found Div 99(SM5): 365-374.

Aydilek, A. H., Edil, T. B. and Fox, P. J. 2000. Consolidation Characteristics of Wastewater Sludge. ASTM Special Technical Publication.

Been, K. and Sills, G. C. 1981. Self-weight Consolidation of Soft Soils: An Experimental and Theoretical Study. Geotechnique 31(4): 519-535.

Berilgen, S. A., Berilgen, M. M. and Ozaydin, I. K. 2006. Compression and Permeability Relationships in High Water Content Clays. Applied Clay Science 31(3-4): 249-261.

Bo, M. W., V. Chao and, A. A. and Na, Y. M. 1999. OneDimension Compression of Slurry with Radial Drainage. Soils and Foundations 39(4): 9-17.

Bo, M. W., Choa, V. and Wong, K. S. 2002a. Compression Tests on a Slurry using a Small-scale Consolidometer. Canadian Geotechnical Journal 39(2): 388-398.

Bo, M. W., Choa, V., Wong, K. S. and The, C. I. 2002 b. Investigation on Deformation Behaviour of High Moisture Content Soil. Soils and Foundations 42(2): 35-46.

Bo, M. W., Sin, W. K., Choa, V. and Ing, T. C. 2003. Compression Tests of Ultra-soft Soil using an Hydraulic Consolidation Cell. Geotechnical Testing Journal 26(3): 310-319.

Bo, M. W., Wong, K. S. and Choa, V. 2004. Investigation on Compressibility of High Moisture Content Soil with Hydraulic Consolidation Cell. Geotechnical Engineering 35(3):133-139.

BS: 1990. British Standard 1377: Methods of Tests for Soils for Civil Engineering Purposes. London: British Standard Institution.

Colleselli, F., G., C. and Cola, S. 2000. Laboratory Testing of Italian Peaty Soils. In Geotechnics of High Water Content Materials, edited by Edil, T.B.a.F., P. J., 226240. ASTM.

Head, K. H. 1986. Manual of Soil Laboratory Testing. Vol. 3. Effective Stress Tests. London: Pentech Press Ltd.

Klein, A. and Sarsby, R. W. 2000. Problems in Defining the Geotechnical Behaviour of Wastewater Sludges. Geotechnics of High Water Content Materials. ASTM.

Koenig, A. Kay, J. N. and Wan, I. M. 1996. Physical Properties of Dewatered Wastewater Sludge for Landfilling. Water Science and Technology 34(3-4-4 pt2):533-540.

Krizek, R. J. 2000. Geotechnics of High Water Content Materials. ASTM Special Technical Publication. pp. 3-29.

Lo, I. M. C., Zhou, W. W. and Lee, K. M. 2002. Geotechnical Characterization of Dewatered Sewage Sludge for Landfill Disposal. Canadian Geotechnical Journal 39(5):1139-1149.

Mesri, G. 1995. Discussion Session. Compression and Consolidation of Clayey Soils. Balkema, Rotterdam.

Mesri, G., Shahien, M., and Feng, T. W. 1995. Compressibility Parameters During Primary Consolidation. Compression and Consolidation of Clayey Soils, edited by Yoshikuni and Kusakabe. Balkema, Rotterdam. (2):1021-1037.

O'Kelly, B. C. 2005. Consolidation Properties of a Dewatered Municipal Sewage Sludge. Canadian Geotechnical Journal 42(5):1350-1358.

Quiroz, J. D., Simpson, P. T. and Zimmie, T. F. 2000. Evaluation of Paper Sludge Landfill Cover Settlement. Geotechnical Special Publication.

Rowe, P. W. and Barden, L. 1966. A New Consolidation Cell. . Geotechnique 16(2): 162.

Yoshikuni, H., Okada, M., Ikegami, S. and Hirao, T. 1995. One-dimensional Consolidation Analysis Based on an Elasto-Viscous Liquid Model. Compression and Consolidation of Clayey Soils, edited by Yoshikuni and Kusakabe. Balkema, Rotterdam. (2):505-512.

N. N. Nik Daud

Department of Civil Engineering, Engineering Faculty, University Putra Malaysia,

Malaysia.

H.R. Thomas \& S.Seetharam

Geo-Environmental Research Centre (GRC),

Cardiff University,

Civil Engineering Department, Cardiff University, United Kingdom.

*Corresponding author; e-mail: niknor@eng.upm.edu.my

Received Date : $3^{\text {th }}$ September 2009

Accepted Date : $22^{\text {nd }}$ July 2010 